27. Kindleberger, Charles P. The world in depression: 1929-1939. Berkeley: University of California Press, 2013.

28. Liptak, Kevin. Jones, Athena. https://edition.cnn.com/2017/06/28/politics/trump-obama-relationship/index.html

29. Lynch, David.J. https://www.washingtonpost.com/news/wonk/wp/2018/01/22/trump-imposes-tariffs-on-solarpanels-and-washing-machines-in-first-major-trade-action/?utm term=.d2134ae20fb1 pink-tide/

30. Main, Alexander. https://www.jacobinmag.com/2017/01/trump-latin-america-foreign-policy-obama-intervention-

31. Mastanduno, Micheal. 'System maker and privilege taker', World Politics 61: 1, 2008

32. Mayer, Jane. https://www.newyorker.com/news/news-desk/in-the-withdrawal-from-the-paris-climate-Agreementthe-koch-brothers-campaign-becomes-overt

33. McCarthy, Tom., Gambino, Lauren. https://www.theguardian.com/us-news/2017/jun/01/republican-senatorsparis-climate-deal-energy-donations

34. McMaster H.R., Gary D. Cohn America First Doesn't Mean America Alone. The Wall Street Journal. May 30, 2017. https://www.wsj.com/articles/america-first-doesnt-mean-america-alone-1496187426

35. Morello, Lauren. https://www.scientificamerican.com/article/ipcc-error-correction-moves-at-glacial-speed/

36. Newport, Frank. http://www.gallup.com/opinion/polling-matters/211682/public-opinion-trump-decision-parisAgreement.aspx?g_source=CATEGORY_CLIMATE_CHANGE\&g_medium=topic\&g_campaign=tiles

37. Obama, Barack. http://science.sciencemag.org/content/355/6321/126

38. Obama, Barack. https://www.nytimes.com/2017/01/10/us/politics/obama-farewell-address-speech.html. open-mind

39. Oliver, Milman. https://www.theguardian.com/us-news/2016/nov/22/donald-trump-paris-climate-deal-change-

40. Parenti, Christian. https://www.jacobinmag.com/2016/01/refugees-europe-merkel-germany-migrants-franceemergency

41. Popken B. Why Trump Killed TPP — And Why It Matters To You. http://www.nbcnews.com/ business /economy/why-trump-killed-tpp-why-it-matters-you-n710781

42. Robin, Corey. https://www.jacobinmag.com/2017/08/trump-afghanistan-imperialism-war-republican-party

43. Stavins, Robert. N. https://www.foreignaffairs.com/articles/2017-06-05/why-trump-pulled-us-out-paris-accord

44. Stivachtis, Dr. Yannis A. American Hegemony and International Order, 2006 (Virginia Polytechnic Institute \& State University). https://www.zgodovina.eu/slovenci/dokumenti/USA\%20hegemony.pdf

45. The Intergovernmental Panel on Climate Change. http://www.ipcc.ch

46. "The Monroe Doctrine (1823)". Basic Readings in U.S. Democracy. United States Department of State. Archived from the original on January 8, 2012.

47. Trump, Donald. https://www.whitehouse.gov/briefings-statements/remarks-president-trump-72nd-session-unitednations-general-assembly/ accord/

48. Trump, Donald. https://www.whitehouse.gov/briefings-statements/statement-president-trump-paris-climate-

49. Trump's withdrawal from Paris is a major blow to the American-led global order. Vox. Jun 1, 2017. https://www.vox.com/world/2017/6/1/15719968/trump-paris-climate-agreement-world

50. Umair, Irfan. https://www.vox.com/energy-and-environment/2018/1/22/16921244/solar-tariff-white-house-itctrump Sheet.pdf

51. US Government Fact Sheet, 2018. https://ustr.gov/sites/default/files/files/Press/fs/201\%20Cases\%20 Fact\%20

52. Wright, Thomas. http://www.politico.com/magazine/story/2016/01/donald-trump-foreign-policy-213546.

DOI 10.31558/2617-0248.2018.3.6

УДК 327 (321.01)

\title{
СТРАТЕГІЯ В ЗОВНІШНІЙ ПОЛІТИЦІ ТА РЕАЛІЗАЦІЇ НАЦІОНАЛЬНИХ ІНТЕРЕСІВ ДЕРЖАВИ: СУТНІСТЬ ТА ЗНАЧЕННЯ
}

\section{Літвін Л. А., к. політ. н., доцент кафедри політології та міжнародних відносин Східноукраїнського національного університету імені Володимира Даля (Україна)}

\begin{abstract}
Метою роботи є визначити сутність та значення стратегії й тактики в зовнішній політиці й реалізації національних інтересів держави. Зазначено, що розвиток та ефективне функціонування сучасної держави неможливі без визначеної стратегії. Реалізація національних інтересів та національної безпеки також повинні підпорядковуватися конкретним стратегіям дій. Вироблена послідовна політична стратегія $\epsilon$ одним із основних факторів ефективної внутрішньої та зовнішньої політики. Акцентовано увагу на тому, що проблемою також постає інтегральність тактичних ходів і стратегічного концепту дій, невідповідність яких може призводити до структурних криз, у тому числі, воєнно-політичного характеру. Надані визначення понять «стратегія», «політична стратегія», «політична тактика», «стратегічне планування». Поняття стратегії досліджено $з$ різних точок зору. Розглянута категорія «мистецтво допустимого».
\end{abstract}

(С) Літвін Л. А., 2018 
Визначені особливості політичної стратегії.

Акцентовано увагу на явищі стратегічного планування. Зазначено, що стратегічне планування сприяє вирішенню низки організаційних завдань, перераховані ці завдання. Означені основні ознаки стратегічного планування. Констатований взаємозв'язок між категоріями «політика» й «стратегія». Описані певні відмінності політичної стратегії від тактики, за дослідженнями вітчизняних учених. Підкреслено, що концепції зовнішньополітичного розвитку та виокремлення основних національних інтересів, а також побудова їх пріоритетності $\epsilon$ найважливішою стратегічною задачею для ефективного розвитку держави. Зазначено, що саме в цих напрямах яскраво виявляється значення стратегії й стратегічного планування в політичній і зовнішньополітичній сферах, а особливої ролі тут набувають стратегічні інтереси.

Виокремлені основні риси ефективної стратегії в зовнішній політиці держави: обов'язкова відповідність стратегії та тактичних дій; визначення конкретного зовнішньополітичного курсу відповідно стратегічних і тактичних дій; ідеологічна підтримка зовнішньополітичної стратегії; наявність "точок контролю», тобто досягнення певних «проміжних» цілей; визначення конкретних стратегій реалізації національних інтересів; відповідність меті засобів її досягнення; стабільність політичної ситуації; раціональне зовнішньополітичне партнерство; контроль над прийняттям рішень.

Ключові слова: політична стратегія, політична тактика, стратегічне планування, зовнішня політика, національні інтереси.

Litvin L. A. The strategy in the foreign policy and the realization of national interests: essence and meaning. The purpose of the paper is to determine the essence and significance of the strategy and tactics in foreign policy and the realization of the national interests of the state. It is noted that the development and effective functioning of the modern state is impossible without a definite strategy. The realization of national interests and national security must also be subject to specific strategies of action. A coherent political strategy developed is one of the key factors for effective domestic and foreign policy. The emphasis is placed on the fact that the problem is also the integration of tactical moves and the strategic concept of action, the mismatch of which can lead to structural crises, including military-political character. The definition of concepts "strategy", "political strategy», "political tactics», "strategic planning» is given. The concept of strategy is investigated from different points of view. The category "art of permissible» is considered. Peculiarities of political strategy are defined.

The focus is on the category of strategic planning. It is noted that strategic planning contributes to the solution of a number of organizational tasks, listed these tasks. These are the main features of strategic planning. The relationship between the categories "politics» and "strategy" is established. Described some differences in the political strategy of tactics, according to research by domestic scientists. It was emphasized that the concepts of foreign policy development and the separation of the main national interests, as well as the construction of their priority, are the most important strategic task for the effective development of the state. It is noted that exactly in these directions the importance of strategy and strategic planning in the political and foreign policy spheres is highlighted, and strategic interests are gaining a special role here.

The main features of an effective strategy in the foreign policy of the state are singled out: compulsory compliance of strategy and tactical actions; definition of a specific foreign policy course in accordance with strategic and tactical actions; ideological support for the foreign policy strategy; the presence of "points of control», that is, the achievement of certain «intermediate» goals; definition of concrete strategies for the realization of national interests; conformity of the purpose of means of its achievement; the stability of the political situation; rational foreign policy partnership; control over decision making.

Key words: political strategy, political tactics, strategic planning, foreign policy, national interests.

Розвиток та ефективне функціонування сучасної держави неможливі без визначеної стратегії. Вироблена послідовна політична стратегія є одним із основних факторів ефективної внутрішньої та зовнішньої політики. Реалізація національних інтересів та національної безпеки також повинні підпорядковуватися конкретним стратегіям дій. В свою чергу саме в реалізації зовнішньої політики розкривається сутність та значення політичної стратегії як специфічного плану розвитку держави на міжнародній арені. Без чітко означених стратегії й тактики національні інтереси держави не будуть досягатися системно й ефективно. Більше того, недотримання стратегічного планування в сфері національних інтересів уможливлює появу або поглиблення стагнацій, недовіри та конфліктності в суспільстві, а також здійснює негативний вплив на геополітичні процеси. Тому констатуємо актуальність даного дослідження. Чинною проблемою також постає інтегральність тактичних ходів і стратегічного концепту дій, невідповідність яких може призводити до структурних криз, у тому числі воєнно-політичного характеру.

Метою роботи є визначити сутність та значення стратегії й тактики в зовнішній політиці та реалізації національних інтересів держави.

Не дивлячись на те, що проблема стратегічного планування у вітчизняній внутрішній та зовнішній політиці $€$ достатньо актуальною, в наукових доробках ця тематика розкривається досить не часто. Більшість робіт 3 проблеми стратегій управління належать до сфери менеджменту та військово-оборонного комплексу. Так, визначення 
категорій політичних стратегії й тактики знаходимо в енциклопедичних політологічних словниках. Фундаментальні роботи з цього питання належать українському досліднику Г. Почепцову, праці якого присвячені, зокрема, стратегічному аналізу в політиці й управлінні. Стратегію й тактику в державному управлінні розглядає В. Тертичка. Стратегії прийняття політичних рішень, зокрема, в контексті аналізу політичної влади, аналізує Б. Кухта. Український учений П. Мироненко вивчає політичну стратегію й тактику в умовах нестабільності суспільнодержавного розвитку. А. Пойченко розглядає політичну стратегію й тактику в контексті технологій політичної діяльності. В той же час недостатньо представлені дослідження стратегій й тактик у зовнішній політиці держави, а також у збереженні й реалізації національних інтересів і національної безпеки сучасних держав.

Узагалі, стратегія (дав.-гр. $\Sigma \tau \rho \alpha \tau ү \gamma і \alpha$ - мистецтво полководця) - це загальний, не деталізований план певної діяльності, який охоплює тривалий період часу, спосіб досягнення складної цілі.

Стратегію можна розгляди як довгостроковий, послідовний, конструктивний, раціональний, підкріплений ідеологією, стійкий до невизначеності умов середовища план, який супроводжується постійним аналізом та моніторингом в процесі реалізації та спрямований з певною метою на досягнення успіху в кінцевому результаті. Стратегія має здатність переходити від абстракції до конкретики у вигляді конкретизованих планів для політичних інститутів [2;9]. Тобто без стратегії зовнішня політика перетвориться на неефективні хаотичні дії, що можуть призвести до кризових ситуацій, невизначеності зовнішньополітичного курсу, ізольованості.

Американнський дослідник Дж. Стейнер, один з основоположників стратегічного планування, пропонує ряд підходів до визначення поняття стратегії:

- стратегія має відношення до основних керівних і спрямовуючих рішень, тобто, до місії і призначення;

- стратегія включає в себе значимі дії, необхідні для реалізації цих рішень;

- стратегія відповідає на питання: як ми бачимо себе в майбутньому? Які наші цілі та шляхи їх досягнення? $[11$, c. $9-12]$.

Стратегія, згідно М. Роберту, в широкому сенсі має відношення до складної павутини, де переплітаються ідеї, осяяння, досвід, знання, спогади, сприйняття й очікування, які задають загальну спрямованість для конкретних дій, спрямованих на досягнення певних цілей. Стратегія являє собою загальну рамкову структуру, що направляє нас у виборі рішень, дій та в той же час зазнає змін під впливом прийнятих рішень і здійснюваних дій.

Інші дослідники, А. Томпсон та А. Стрикленд, визначають стратегію як комбінацію із запланованих дій і швидких рішень по адаптації до нових досягнень промисловості й нової диспозиції на полі конкурентної боротьби. М. Портер зазначає, що стратегія - це спосіб реакції на зовнішні можливості й загрози, внутрішні сильні й слабкі сторони [10].

У свою чергу політична стратегія - визначення довготривалої мети, широкої програми дій, повсякденних завдань, загальної довготривалої лінії політичної поведінки, основних напрямків діяльності, науково обгрунтованого розвитку реальних політичних подій і явищ тощо. Стратегія визначає і забезпечує основний напрямок політичної діяльності суб'єктів влади та політики. Ї̈̈ об'єктом є вироблення головної мети, програм на певному етапі політичної діяльності суб'єктів політики, шляхів та мір їхнього досягнення. В умовах демократизації громадського життя визначаються основна ланка, головний напрямок у політичному процесі, черговість політичних проблем, що вирішуються [4].

Першоджерела, в яких проаналізовані стратегія й тактика, стосуються в першу чергу воєнного мистецтва. Найяскравішими роботами можна назвати «Мистецтво війни» Сунь-Цзи та «Про війну» К. фон Клаузевіца. Так, К. фон Клаузевіц, якому належить відомий вислів «Війна є продовження політики іншими засобами», у своїй роботі стверджує, що тактика є вченням про використання військових сил у бою, а стратегія - вчення про використання боїв у цілях війни. «Тактика і стратегія представляють дві в просторі і часі один одного проникаючі, але в той же час по суті різні діяльності; ми ні в якому разі не можемо чітко мислити їх внутрішні закони і взаємини, відмови від встановлення в точності їх поняття» [2].

Як зазначає український дослідник В. Мироненко, полі-тична стратегія і тактика виступають чинниками оптимізації функціонування системи державного управління, дозволяючи внести елементи визначеності щодо майбутнього перебігу внутрішньодержавних політичних процесів, надаючи достатній обсяг знань та альтернатив для того, щоб здійснювати керо ᄀваний вплив на політичні процеси, події та явища, забезпечуючи легітимацію політико-владної діяльності як засіб подолання політичної нестабільності. Також В. Мироненко підкреслює, що особливістю політичної стратегії за сучасних умов, надто у кризових ситуаціях, є те, що вона має бути спрямована саме на агресивне зовнішне середовище, вміти адекватно реагувати на «виклики» та ризики глобалізації. Наявність розробленої та ефективної політичної стратегії є свідченням політичної сили, могутності держави [4].

Інший український учений В. Колпаков, стверджує, що, виходячи з аналізу взаємозв'язку основних категорій, можна зробити висновок про те, що різні тлумачення терміну «політика» залежать від розуміння інтерпретації окреслених цілей, завдань і функцій. Центральною категорією виступає політична мета діяльності владної еліти. Вона визначає політичну стратегію й, відповідно, стратегію освіти, методи й технології стратегічного управління, спрямованість політичної діяльності [3].

Говорячи про стратегію, не можна не розглянути таке поняття як тактика в зовнішній політиці держави. Тактика - це частина стратегії, політична лінія суб'єктів політики на порівняно нетривалий період; це сукупність шляхів, форм, прийомів, методів та засобів реалізації політичних ідей, програм, досягнення головної мети й завдань стратегії. Політична тактика випливає з політичної стратегії і підпорядковується їй. Політична стратегія і політична тактика - складові політичного керівництва, орієнтири в міжнародній політиці, тісно пов'язані між собою. Свобода вибору народом соціально-політичного ладу, зовнішньополітичного курсу, формування та збереження національних 
інтересів, відмова від війни як засобу й методу вирішення міжнародних проблем, глобалізований вимір політики тощо - все це характерне для сучасної стратегії й тактики в зовнішній політиці держав [2].

Відомий український дослідник Г. Почепцов аналізує проблему стратегії й тактики як у теоретичному, так і в прикладному аспектах. Він описує певні відмінності політичної стратегії від тактики:

- стратегія працює у межах багатовимірного простору, управляючи не лише прихильниками, але й противниками, опонентами, а тактика функціонує в одновимірному середовищі, спрямовуючи свої дії виключно на прихильників;

- стратегія працює за принципом багатьох кроків, а тактика передбачає тільки один хід; стратегія конструює майбутній і віртуальний простір, а тактика спрямована на сьогодення і реальний простір;

- стратегія передбачає зміну точок зору, а тактика - дотримання однієї з них;

- стратегія має спрямовуватися від розширення поля можливостей до розширення поля дій через зміну правил гри [8, с. 44].

Конструктивна політична стратегія передбачає прогресивний політичний і економічний розвиток держави, конструктивний вибір засобів і методів іiі здійснення (мистецтво компромісів, договірні стосунки, попередження екстремальних ситуацій, зростання ролі міжнародного права, здійснення превентивної дипломатичної діяльності, уникнення воєнних дій, звернення та урахування громадської думки тощо), формування позитивного іміджу держави на міжнародній арені, стабільність міжнародних відносин [6].

Важливою ланкою у виробленні стратегії й тактики у зовнішній політиці стає процес прийняття рішень, постановка мети й завдань. Їх підготовка пов'язана із з'ясовуванням позицій та поглядів основних політичних сил країни, що пропонуються у вигляді альтернатив, їх рівень - свідчення про потенціал політичних суб'єктів. Відомо, що ефективність так званої мітингової демократії не висока. Створюючи політичний настрій, мітингова демократія не вносить його в межі народних інтересів, що реалізуються, не створює необхідного політичного механізму для реалізації політичного настрою. Важливо у політичній діяльності чітко визначити ефективність та реалістичність рішень, уникаючи так званих закличних рішень, що не є конкретно організованими, хоча можуть бути гасла, розраховані на формування необхідних політичних орієнтирів у громадській свідомості [4].

Для організації політичної діяльності з реалізації певної мети та рішень особливе значення має вибір засобів. Відомий вираз: «політика $є$ мистецтво допустимого». Мистецтво компромісів має умовне ставлення до засобів реалізації стратегічних та тактичних рішень, тому що в політичному рішенні вибір засобів відіграє вирішальну роль, від цього залежить успіх. Тому мистецтво допустимого - це набір засобів, що відповідають стабільності обстановки, але не екстремальний варіант, коли допустиме рішення оперативно змінюється. При такому підході й політичний компроміс також має конкретний зміст, виступаючи у значенні можливого, але не завжди допустимого засобу [7].

Потрібно вміти політично маневрувати, визначити час, поле наступу і відступу, змінюючи тактику при переході від атак до оборони тощо. Політичний маневр, розрахований на пізнання можливості утримати позиції, набутий в процесі реалізації тієї чи іншої політичної акції, необхідного потенціалу для реалізації та досягнення мети. В раціонально організованій політичній діяльності маневр - постійне врахування ситуацій, що виникають, та вміння перерозподіляти політичні сили, тобто маневрувати, що характерно для дипломатичної діяльності, для тих держав, що намагаються не шляхом військових засобів, а шляхом урахування загальних обставин, консенсусу, інформаційних технологій розвиватися на міжнародній арені.

Як у зовнішньополітичній, так і внутрішньополітичній діяльності необхідно уміти наступати й відступати. Політична стратегія наступу, як правило, передбачає прийняття політичними інститутами певних рішень про наступ. Чи мале політичне навантаження виконує й політичний відступ. Вчасно відступити для того, щоб, зберігши сили, набратися нової енергії, потім піти у наступ і добитися успіху тощо [4].

Нейтралізація передбачає також перевірку можливої зміни інших політичних ресурсів, досягнення результативності політичної діяльності. Тут має значення політичний контроль. Поняття «ситуація контролюється», поширене у політичній практиці, означає локалізацію сил, що має право контролю політичної поведінки об'єкту, стабільність стану, що знаходиться в центрі уваги. Заставою ефективності політичної діяльності $\epsilon$ організація каналів зворотного зв'язку з об'єктом політичної діяльності або зовнішнім партнером. Змістом і метою стратегії і тактики в зовнішній політиці держави є вплив на прийняття та здійснення політичних рішень у русі зовнішньополітичного процесу [6].

Говорячи про стратегію в політиці, в тому числі, в зовнішній політиці, не можна не означити питання стратегічного планування в політичній і міжнародній сферах. Так, український дослідник С. Туронок зазначає, що стратегічне планування є тим різновидом діяльності, який в найбільш повній формі розкриває її політичний аспект. Стратегія являє собою міст між «політичними» цілями вищого порядку з одного боку і тактикою або конкретним планом дій - з іншого.

Стратегічне планування сприяє вирішенню низки організаційних завдань: ясне визначення сенсу існування організації і встановлення реалістичних цілей і завдань, сумісних з цим баченням; донесення цих цілей і завдань до сторін, зацікавлених у діяльності даної організації; вироблення відчуття причетності до планових цілей і завдань 3 боку керівництва, персоналу, спонсорів та інших стейкхолдерів даної організації; сприяння найбільш ефективному використанню організаційних ресурсів шляхом їх фокусування на ключових пріоритетних завданнях; формулювання бази для вимірювання досягнутого прогресу і вироблення механізму осмисленого зміни, якщо в цьому $є$ необхідність. Стратегічне планування починається з ідентифікації та поновлення того, що можна назвати «стратегічною філософією» організації. Йдеться про переосмислення організаційної місії, бачення, ціннісних орієнтирів [10]. 
Процес стратегічного планування володіє специфічною структурою, що відрізняється від базової структури планування. Його ключовими етапами, згідно Дж. Стейнера, є: формулювання місії; формулювання бачення; ідентифікація цінностей; стратегічний аналіз (внутрішній і зовнішній); планування стратегії діяльності; планування комунікації; імплементація стратегії [11, с. 53 - 80].

Українські дослідники В. Горбатенко та І. Бутовська пропонують такі основні ознаки стратегічного планування:

Багатоваріантність. Орієнтує на пошук оптимального шляху задля досягнення запланованої мети. Ефективність жодної обраної стратегії неможливо передбачити абсолютно, а лише з певною вірогідністю. Остаточно стратегія визначається лише тоді, коли реалізується в житті. Оптимальною є така пошукова стратегія, що передбачає одночасний рух у кількох паралельних напрямах i, якщо це можливо, прийняття таких рішень, які відіграють важливу роль у кількох стратегічних напрямах. Тому на цьому етапі необхідною стає гармонізація варіантів, їх узгодження на рівні, який можна визначити як метастратегічний. Тоді йтиметься про співвідношення стратегій у ціннісному аспекті, коли одна із стратегічних ліній визначається як провідна, а інші - як підпорядковані, тобто їх введення в дію залежатиме від того, як втілюватиметься в життя домінуюча стратегія.

Цілісність. Передбачає орієнтацію на кінцеву мету та взаємоузгодженість варіантів стратегій. Будь-яка стратегія повинна бути концептуально окресленою як стосовно початкових умов здійснення, так і щодо кінцевого результату. Початковий аналіз охоплює наявні ситуації, ресурси та можливості. Кінцевий аналіз передбачає грунтовну оцінку витрат щодо досягнення мети, тобто чи дійсно мета виправдовує засоби. Але слід зважати на той факт, що не завжди можна все прорахувати. Іноді в історичний процес втручаються такі сили, які не можуть бути помічені та враховані при розробленні стратегічних планів. Тому нерідко буває так, що наділені владою особи планують одне, а виходить щось зовсім інше, що не передбачалося. Саме тому принцип відповідності засобів і мети дає змогу деякоюмірою запобігти небажаним наслідкам тих або інших дій. Тобто якщо навіть мета не буде досягнута, то можна передбачати мінімальні втрати при ії досягненні.

Послідовність. Міркування щодо усвідомлення інтересів не претендують на вичерпність, але дають змогу окреслити напрями руху, в яких таке усвідомлення стає можливим і необхідним. Головною методологічною передумовою цього процесу є логіка і послідовність. Проте соціально-політичні реалії часто бувають такими, що іноді після того, як зроблено перший крок, ми вагаємося зробити наступний. Ми або зупиняємося, або намагаємося ще раз усвідомити, чи правильно все зрозуміли і зробили із самого початку. Відсутність логіки в мисленні призводить до непослідовності дій, і тоді складається ситуація, коли суб'єкт суперечить сам собі, тобто тупцює на місці. Це свідчить про особливе значення волі суб'єкта при здійсненні стратегічних намірів.

Суб'єктивне (морально-вольове) начало. Нерідко, розмірковуючи про суб'єкта стратегічного мислення, особливу увагу приділяють його розумовим, вольовим та духовним якостям. Це пов'язано з тим, що саме воля, яка $\epsilon$ моральною величиною, дуже часто виступає рушійною силою. Проте саме ці якості щонайменше піддаються грунтовному науковому аналізу [1, с. $51-52]$.

Таким чином, констатуємо безпосередній зв'язок між політикою й стратегією. Сама політика має бути стратегічною діяльністю, а суб'єкт прийняття політичних (зовнішньополітичних) рішень - стратегом. Визначення концепції зовнішньополітичного розвитку та виокремлення основних національних інтересів, а також побудова їх пріоритетності є найважливішою стратегічною задачею для ефективного розвитку держави. Саме в цих напрямах яскраво виявляється значення стратегії й стратегічного планування в політичній і зовнішньополітичній сфері. Особливої ролі тут набувають стратегічні інтереси. Можна виокремити основні риси ефективної стратегії в зовнішній політиці та реалізації національних інтересів держави: обов'язкова відповідність стратегії та тактичних дій; визначення конкретного зовнішньополітичного курсу відповідно стратегічних і тактичних дій; ідеологічна підтримка зовнішньополітичної стратегії; наявність «точок контролю», тобто досягнення певних «проміжних» цілей; визначення конкретних стратегій реалізації національних інтересів; відповідність меті засобів іії досягнення; стабільність політичної ситуації; раціональне зовнішньополітичне партнерство; контроль над прийняттям рішень.

Перспективами подальших досліджень $є$ визначення конкретних стратегії й тактик у реалізації національних інтересів сучасної України, а також аналіз сучасних можливих стратегій у зовнішній політиці держави.

\section{Бібліографічний список:}

1. Горбатенко В. П. Політичне прогнозування : [Навчальний посібник] / В. П. Горбатенко, І. О. Бутовська. К. : МАУП, 2005. - 152 c.

2. Клаузевиц К. О войне. Избранное [Електронний ресурс] / Карл фон Клаузевиц; пер. с нем. А. К. Рачинского. - Режим доступу : https://royallib.com/read/klauzevits_karl/o_voyne.html\#88781

3. Колпаков В. Поняття «політика» і «стратегія» у світлі проблем сьогодення [Електронний ресурс] / Віктор Колпаков // Персонал. - 2014. - № 6. - Режим доступу : http://persona-l.pp.ua/rubrics/ekonomka-poltika1/ponyattyapoltika-strategya-u-svtl-problem-sogodennya

4. Коротец И. Д. Политология: [Словарь] [Електронний ресурс] / Коротец И. Д. - Р-н-Д. : РГУ В. Н. Коновалова, 2010. - Режим доступа: http://dic.academic.ru/ dic.nsf/politology/183/

5. Мироненко П. В. Методологічні основи політичної стратегії і тактики як системи засобів подолання політичної нестабільності [Електронний ресурс] / Петро Володимирович Мироненко // Політичні інститути та процеси. - 2016. - № 1. - С. 29 - 33. - Режим доступу : http://elibrary.ivinas.gov.ua/325/1/suspilno-politychniprotsesy_1-29-33.pdf

6. Політологічний енциклопедичний словник / [За ред. Ю. С. Шемшученка, В. Д. Бабкіна]. - 2-е вид., доп. і перероб. - К. : Генеза, 2004. - 736 с. 
7. Політологія : навчальний енциклопедичний словник довідник для студентів BHЗ I-IV рівнів акредитації / За наук. ред. д-ра політ. н. Хоми Н. М. [В. М. Денисенко, О. М. Сорба, Л. Я. Угрин та ін.]. - Львів : «Новий Світ 2000», 2014. - 779 c.

8. Почепцов Г. Г. Стратегический анализ. Стратегический анализ для политики, бизнеса и военного дела / Георгий Георгиевич Почепцов. - К. : Дзвін, 2004 - 333 с.

9. Сунь-Цзы. Искусство войны [Електронний ресурс] / Сунь-Цзы ; пер. Н. Конрада. - Режим доступу : http://librebook.me/the_art_of_war

10. Туронок С. Г. Політичнй аналіз і прогнозування [Електронний ресурс] / Станіслав Генріхович Туронок. - Режим доступу : https://stud.com.ua/43949/politologiya/politichniy_analiz_i_prognozuvannya

11. Steiner G. A. Strategic Planning [Електронний ресурс] / George A. Steiner. - NY : Simon and Schuster, 2010. - 400 с. - Режим доступу : https://books.google.com.ua/books?id=EXoPC22vb4oC \&printsec=frontcover\&hl= $\mathrm{ru} \# \mathrm{v}=$ onepage $\& \mathrm{q} \& \mathrm{f}=$ false

DOI 10.31558/2617-0248.2018.3.7

УДК 327.7

\section{ТИМЧАСОВА АДМІНІСТРАЦІЯ ООН ЯК ПЕРШИЙ ЕТАП ДЕРЖАВНОГО БУДІВНИЦТВА}

\section{Стойко О. М., д. політ. н., Інститут держави і права ім. В.М. Корецького НАН України}

Проаналізовано досвід і наслідки впровадження тимчасової адміністрації у рамках миротворчих операцій ООН. У Камбоджі основним завданням тимчасової адміністрації, створеної резолюцією РБ ООН у 1992 році, було проведення виборів, за результатом яких відбулася зміна державного ладу країни та припинено тривалу громадянську війну.

У Хорватії запровадження тимчасової адміністрації в 1995 році було передбачено мирною угодою між урядом та представниками сербів, які брали участь у створенні самопроголошеної Республіки Сербська Країна, для контролю за процесом демілітаризації та реалізації плану з мирної реінтеграції регіону. Миротворча місія була успішно завершена в 1998 році без зміни державних кордонів.

Фактичне звільнення території Косово від армії Югославії у результаті військової операції НАТО в 1999 році дало змогу РБ ООН прийняти резолюцію про тимчасову адміністрацію, що мала забезпечити безпеку, стабільність, дотримання прав людини та сприяти формуванню основних інститутів держави. Після проголошення незалежності у 2008 році мандат миротворчої місії було змінено, однак територія і надалі залишається потенційним джерелом нестабільності у регіоні.

Створена в 1999 році тимчасова адміністрація у Східному Тиморі спряла реалізації результатів референдуму, на якому більшість мешканців проголосувала за відділення від Індонезії. Виникнення нової держави у 2002 році зумовило зміни у мандаті миротворчої місії, яка у різних формах тривала до 2012 року.

Спільними для останніх трьох випадків є наявність цивільної (адміністративної) та військової (силової) складових у миротворчій операції ООН. Встановлено, що діяльність такого органу на території окремих регіонів країни, що не контролюються урядом, неминуче призводить до створення нових держав та втрати територіальної цілісності, що не відповідає інтересам України при врегулюванні конфлікту на Донбасі.

Ключові слова: тимчасова адміністрація, миротворча операція, територіальна цілісність, право народів на самовизначення.

Stoyko O. M. UN transitional administration as the first stage of state building

The experience and implications of the introduction of the transitional administration within the framework of UN peacekeeping operations have been analyzed. In Cambodia, the main task of the transitional administration, established by the UN Security Council resolution in 1992, was the holding of election, which resulted in a change in the state structure and the end of a long civil war.

In Croatia, the introduction of the transitional administration in 1995 was foreseen by a peace agreement between the government and representatives of the Serbs who participated in the creation of the selfproclaimed Republic of Serbian Krajina, to monitor the process of demilitarization and to implement the plan for the peaceful reintegration of the region. The peacekeeping mission was successfully completed in 1998 without changing the state borders.

The actual liberation of Kosovo's territory from the Yugoslav Army as a result of NATO's military operation in 1999 allowed the UN Security Council to adopt a resolution on a transitional administration that was supposed to ensure security, stability, human rights and promote the formation of the main institutions of the state. After the declaration of independence in 2008, the mandate of the peacekeeping mission has been changed, but the territory remains a potential source of instability in the region. 